\title{
Visualisasi Data Lokasi Rawan Bencana Di Provinsi Sumatera Selatan Menggunakan Tableau
}

\author{
Septy Angreini \& Edi Supratman \\ Fakultas Ilmu Komputer, Universitas Bina Darma \\ Email: septyangreini21@gmail.com
}

\begin{abstract}
The BPBD of South Sumatra Province is one of the non-departmental government institutions that is directly supervised by the Central BNPB, one of which is the task of the South Sumatra BPBD to have information about disasters in the Regency/City of the South Sumatra region. However, the annual disaster reporting has not been published so that the people of South Sumatra do not know the disaster-prone locations in each area of the South Sumatra region. The purpose of this study is to create a visualization in the form of dashboard information using Tableau from data on disaster-prone areas of South Sumatra Province in each Regency/City. Based on the results of the visualization, it was found that the area that often occurs in disasters is Musi Rawas Regency with the type of flood disaster, each year the areas that are often affected are OKU Regency, Muratara Regency, and East OKU Regency, while for disasters that often occur from several disasters, namely floods and flash floods with the number of victims affected is always high.
\end{abstract}

Keywords: Visualization, Dashboard, Disaster, Tableau, BPBD.

\section{Pendahuluan}

Bencana alam merupakan kejadian yang tidak dapat dihindari, akan tetapi dampak dari bencana alam dapat dikurangi atau diminimalisir dengan mengetahui penyebab bencana tersebut dan mempelajari kejadian bencana yang telah terjadi sebelumnya (Darman, 2018). Indonesia merupakan daerah yang rawan terjadinya bencana dikarenakan secara geografis Indonesia berbentuk Negara kepulauan yang terletak pada pertemuan tiga lempeng besar yaitu lempeng Eurasia, lempeng pasifik, dan lempeng Australia yang bergerak saling menumbuk atau konvergen (Khakimuddi, 2018).

Indonesia adalah negara yang sudah rawan terhadap bencana alam seperti gempa, banjir, badai, tanah longsor, letusan gunung berapi, dan kebakaran hutan. Bencana terkait banjir dan angina kencang mencakup sekitar 70\% dari total bencana dan sisanya 30\% terkait dengan gempa, tanah longsor, kebakaran hutan, dan yang lainnya (Priangga et al, 2017). Oleh sebab itu pemerintah Indonesia menetapkan dalam UU nomor 24 tahun 2007 mengenai Badan Penanggulangan Bencana Daerah (BPBD).

BPBD Sumatera Selatan merupakan salah satu lembaga pemerintah non departemen yang melaksanakan tugas penanggulan bencana didaerah baik Provinsi maupun Kabupaten/Kota untuk Provinsi Sumatera Selatan dengan pedoman pada kebijakan yang ditetapkan oleh Badan Nasional Penanggulan Bencana (BNPB) (Sumaja, 2018). Informasi mengenai bencana yang terjadi pada setiap Kabupaten/Kota ke Provinsi dan ke Pusat yang dilaporkan tidak selalu diperbaharui disetiap tahunnya untuk dilihat ke publik oleh sebab itu masyarakat banyak belum mengetahui lokasi rawan bencana disetiap daerah.

Melihat fungsi dan peranan dari BPBD yang sangat penting dalam hal penanggulangan bencana disetiap Kabupaten/Kota yang ada di Provinsi Sumatera Selatan, untuk itu diperlukan sebuah informasi dashboard secara umum yang memiliki tampilan yang 
sesuai dan cukup mudah dimengerti.

Penggunaan informasi dashboard berguna untuk mempercepat proses keputusan, mengukur kinerja organisasi/instansi, memonitor proses yang sedang berjalan dan memprediksi kondisi di masa yang akan datang (Darman, 2018).

Informasi dashboard dapat diimplementasikan dengan pemanfaatan Business Intelligence (BI). BI merupakan sebuah proses yang digunakan untuk melakukan analisis data terstruktur untuk melakukan ekstrasi data-data operasional dan mengumpulkannya dalam sebuah data warehouse (Camila et al, 2018). Tableau merupakan salah satu perangkat lunak yang digunakan dalam aplikasi BI, dengan penerapan BI pada Tableau menghasilkan visualisasi data secara interaktif dengan cara meng-import dataset ke dalam Tableau dan membuat visualisasi yang mempermudah dalam memahami suatu informasi. Tableau dapat membangun data dari berbagai sumber data seperti spreadsheet, database, cloud data dan big data (Hartama, 2018).

Visualisasi data yang sudah pernah dilakukan pada penelitian lokasi rawan tanah longsor bahwa data yang di dapat dari BNPB mengenai bencana banjir, tanah longsor, dan pergerakan tanah yang dimana daerah seluruh indonesia diprovinsi dengan data yang diambil dari tahun 2011-2014. Penggunaan Tableau sebagai aplikasi BI untuk memperoleh informasi berupa grafik maupun data yang diperlukan, sehingga hasil yang didapatkan daerah yang paling rawan terjadinya bencana longsor terdapat didaerah pulau jawa dan sumatera. Sedangkan wilayah yang paling aman berada dipulau kalimantan dan papua. Bencana tanah longsor yang sering terjadi pada tahun 2013 (Darman, 2018).

Melihat dari referensi-referensi yang didapat, bahwa pentingnya keterbukaan data untuk publik dalam halnya titik lokasi rawan bencana di setiap Kabupaten/Kota yang ada diwilayah Sumsel supaya masyarakat dapat dengan sigap jika nantinya ada bencana yang akan terjadi dititik lokasi tersebut, hal ini dapat dilihat dari status bencana yang dibuat oleh BPBD Sumsel dari data yang didapatkan nantinya. Data yang akan diambil oleh penulis yaitu dari tahun 2018 sampai 2020.

Informasi bencana yang didapat dari BPBD Sumsel pada bulan Januari hingga Oktober 2020 tercatat ada 149 bencana alam yang terjadi di wilayah Sumatera Selatan, dengan 70 kasus kebakaran rumah penduduk, banjir 39 kasus, tana longsor 16 kasus, angin puting beliung 11 kasus, banjir bandang 10 kasus, dan bencana-bencana kecil lainnya (BPBD, 2020). Dari data yang dapat nantinya akan dianalisis perbandingan bencana yang sering terjadi disetiap tahunnya, daerah yang sering terjadi bencana, korban bencana banjir, bencana yang sering terjadi dan atribut-atribut yang dapat divisualisasikan sehingga mendapatkan suatu informasi dashboard yang dapat dimengerti oleh masyarakat.

Dari latar belakang tersebut, maka penulis melakukan penelitian yang berjudul "Visualisasi Data Lokasi Rawan Bencana Di Provinsi Sumatera Selatan Menggunakan Tableau”. Penulis akan menggunakan implementasi BI dan objek penelitian nantinya di BPBD Provinsi Sumatera Selatan.

\section{Tinjauan Literatur}

\subsection{Visualisasi data}

Visualisasi data merupakan salah satu teknik untuk mengeksplorasi data dengan cara mengubah bentuk data dengan format visual seperti tabel atau grafik sehingga dapat 
dianalisis dan dilaporkan tentang data dan bukti sehingga data yang kompleks menjadi lebih mudah dipahami dan berguna. Visualisasi data dapat diartikan atau dijabarkan sebagai jenis teknik untuk membuat gambar atau animasi dengan tujuan mengkomunikasikan sebuah informasi secara jelas dan efisien kepada pengguna melalui grafik informasi yang digunakan (Camila et al, 2018, dalam B. A. Mihaly, 2008).

Visualisasi merupakan rekayasa dalam pembuatan gambar, diagram atau animasi untuk penampilan suatu informasi. Teknik visualisasi informasi dapat membantu masalah eksplorasi dataset yang besar. Terdapat dua konsep visualisasi yaitu scientific visualisation dan information visualisation, kedua konsep tersebut membuat model grafis dan menampilkan data secara visual yang berinteraksi langsung dengan pengguna. Dalam melakukan dan memperoleh eksplorisasi data pada scientific visualisation, umumnya model grafis dibangun dari pengukuran atau simulasi data yang mewakili objek/konsep yang terkait dengan fenomena yang sebenarnya. Pada information visualisation konsep abstrak dan hubungan tidak selalu memiliki keterkaitan di dunia nyata (Darman, 2018).

Visualisasi data sama halnya seperti berkomunikasi, berhasil atau tidaknya komunikasi ditentukan oleh bagaimana cara pembicara menyampaikan informasi yang diberikan kepada lawan komunikasi. Visualisasi yang baik tentu terfokus, memberikan jawaban yang jelas, dan tidak terlalu detail. Untuk mencapai visualisasi yang baik dilakukan proses visualisasi data (Syaripul, 2016).

Dapat disimpulkan bahwa visualisasi data merupakan teknik dalam mengeksplorasi data dengan tampilan yang berbeda dari data asli, sekaligus untuk menganalisis data.

\subsection{Business Intelligence}

Business Intelligence merupakan kecerdasan bisnis yang mengkombinasi dari arsitektur, tools, basis data, aplikasi, dan metodologi untuk dapat dilakukannya akses data secara, interaktif, manipulasi data dan memberikan kemampuan membuat keputusan bisnis yang baik kerena digunakan fakta dan sistem yang berdasarkan fakta (Hafidz et al, 2019). BI termasuk teknologi yang digunakan untuk menyajikan data-data dan mempermudah analisis dalam mengambil keputusan berdasarkan informasi yang akurat dari sumber data. Suatu solusi bussiness intelligence yang baik memerlukan sumber data yaitu data warehouse (Qudsi, 2018).

Business Intelligence yaitu sebuah proses untuk melakukan ekstraksi data-data operasional perusahaan dan mengumpulkannya dalam sebuah data warehouse. Data yang diolah dapat dijadikan dalam pengambilan keputusan berdasarkan fakta-fakta aktual dan tidak hanya mengandalkan intuisi dan pengalaman kuantitatif saja (Alfarizi et al, 2018). $B I$ bertujuan untuk menyajikan berbagai informasi yang disesuaikan dengan kebutuhan setiap penggunanya. Informasi tersebut dapat berasal dari mana saja, misalnya dari data histori pembelanjaan, data pelaporan dan data-data yang masih dalam data mentah (Antoni, Fikari \& Akbar, 2018; Antoni \& Akbar, 2019; Antoni, Jie \& Abareshi, 2020; Antoni, Herdiansyah, Akbar \& Sumitro, 2021).

Adapun solusi yang didapatkan dari pemanfaatan BI (Akbar et al, 2018) yaitu:

1. Mengidentifikasi masalah bisnis yang perlu diselesaikan dengan data warehouse dan menentukan data (penentuan atribut) yang diperlukan untuk menyelesaikan masalah. 
2. mengidentifikasi lokasi dari data-data yang diperlukan dan mengambilnya dari sumber penyimpanannya.

3. Mengubah data yang diperoleh dari beragam sumber tersebut ke dalam sebuah data yang konsisten (Cleaning data).

4. Mengambil data yang telah diubah tersebut ke dalam lokasi yang yang tersentralisasi (transform data).

5. Membuat sebuah data warehouse dengan data yang ada dalam lokasi yang tersentralisasi tersebut.

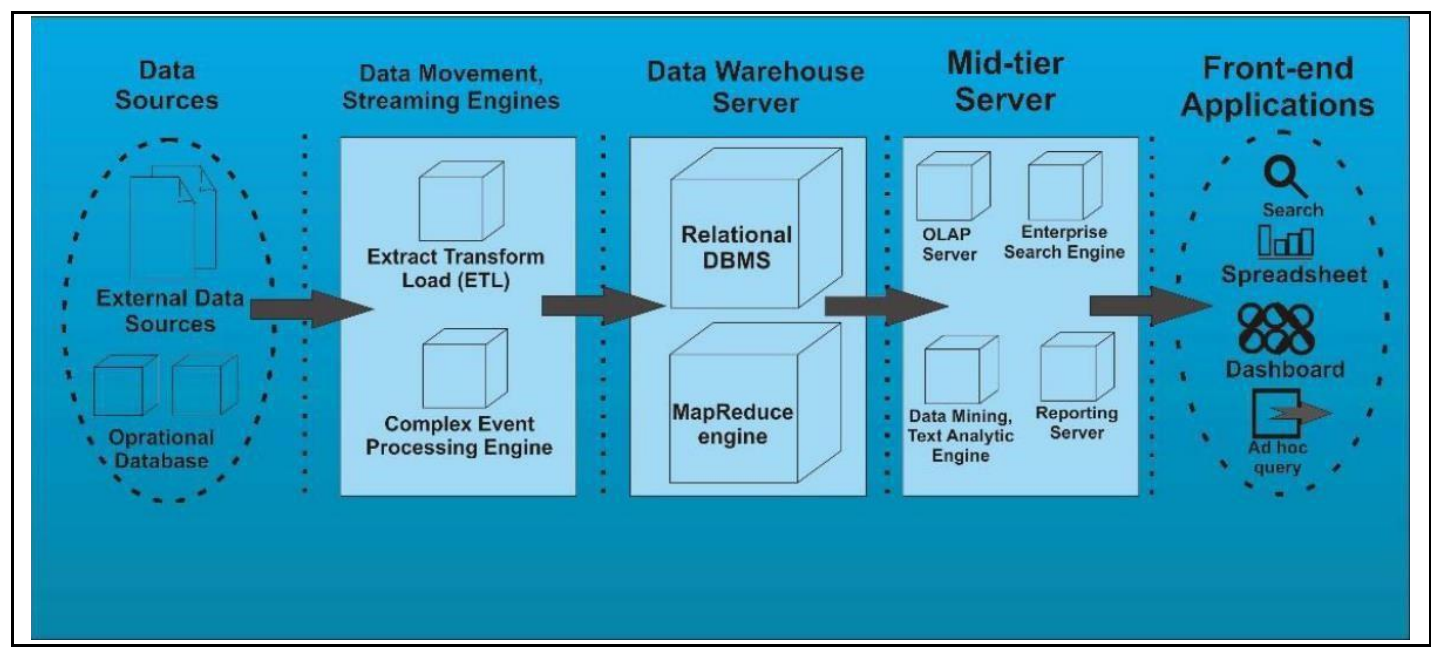

Gambar 2. 1 Komponen Business Intelligence

Dapat diambil kesimpulan bahwa business intelligence merupakan tools yang sangat berfungsi untuk menganalisis data dan mengelola data secara interaktif, mempermudah dalam pengambilan proses keputusan bisnis berdasarkan fakta-fakta aktual dan mendapatkan informasi yang berkualitas dari kegiatan bisnisnya.

\subsubsection{Tahapan Business Intelligence}

Business Intelligence memiliki beberapa tahapan dalam pengolahan datanya berikut tahapan yang digunakan menurut Atsani et al (2019).

1. Data Source, yaitu sumber data yang akan digunakan untuk membuat data warehouse. Sumber data biasanya didapat dari database

(sqlserver, oracle, mysql) dan juga dalam format file ( $x l s x, c s v, x m l$, dan json).

2. Extract Transform Loading (ETL), merupakan suatu proses pengolahan/Penyaringan data dari database transactional ke data warehouse.

3. Data warehouse, ialah database yang dibuat untuk menganalisis dan pelaporan, beberapa model yang biasa digunakan dalam pembuatan data warehouse yaitu model skema bintang dan skema snowflake.

4. Data model, yaitu metode yang digunakan untuk melakukan analisis data dari data warehouse secara multidimensi.

5. Dashboard, merupakan bentuk visualisasi data dalam bentuk teks, peta maupun grafik. 


\subsection{Information Dashboard}

Dashboard ialah tampilan visual dari informasi penting yang diperlukan untuk memahami dan mengelolah suatu organisasi yang dikelola sehingga dapat menyelesaikan penyajian dan visualisasi data, dengan menggunakan sistem dashboard, data dan informasi strategis dapat ditampilkan dengan online, cepat, dan mudah (Darman, 2018).

Penggunaan informasi dashboard berguna untuk mempercepat proses keputusan, mengukur kinerja organisasi/instansi, memonitor proses yang sedang berjalan dan memprediksi kondisi di masa yang akan datang (Darman, 2018). Dashboard merupakan tools dan menyajikan key perfomence indicators (KPI) merupakan indikator utama dari kinerja suatu proses yang berlangsung pada sebuah organisasi yang menampilkan dalam satu layar untuk memudahkan suatu proses sehingga dapat meningkatkan proses bisnisnya (Camila et al, 2018). Terdapat beberapa prinsip yang harus diperhatikan dalam membuat dashboard, yaitu :

1. Menyediakan informasi berupa key performance indicator yang spesifik.

2. Melakukan integrasi beberapa informasi dalam 1 layar.

3. Bersifat interaktif dan informasi yang saling terintegrasi.

4. Melakukan analisis, monitoring, dan prediksi dalam 1 waktu.

5. Dapat bersifat personal menyesuaikan kebutuhan dari penggunaan.

6. Memeungkinkan berkolaborasi dan komunikasi antar bagian divisi (Nurmalasari et al, 2015).

Dashboard ialah turunan dari sistem informasi eksekutif dan sistem pendukung keputusan dengan memiliki sistem data yang kuat dengan memanfaatkan key performance indicator. Ada 3 jenis information dashboard yaitu :

1. Tactical Dashboard, bertujuan untuk mengukur produktivitas dan efektivitas dalam jangka pendek, biasanya digunakan pada individu.

2. Operational Dashboard, untuk mengukur fungsi bisnis yang spesifik, atau tingkat unit bisnis dalam jangka pendek, biasanya digunakan untuk pekerjaan tim.

3. Strategic Dashboard, dipergunakan untuk tingkatan pengaturan kebijakan dari sebuah perusahaan / organisasi / instansi (Imam, 2016).

Dapat diambil kesimpulan bahwa dashboard merupakan tools yang menampilkan tampilan visual dari informasi guna untuk memahami dan mengelola suatu bidang organisasi yang dikelola pada satu layer yang berguna untuk mempercepat proses keputusan, mengukur kinerja organisasi dan memonitor proses yang sedang berjalan.

\subsection{Bencana}

Dalam UU No 24 Tahun 2007, bencana yaitu peristiwa yang mengancam dan mengganggu kehidupan dan penghidupan masyarakat. Adapun kelompok penyebab terjadinya bencana di Indonesia dibagi menjadi 3 (Indonesia, 2007), yaitu:

1. Bencana alam merupakan bencana yang diakibatkan oleh peristiwa atau serangkaian peristiwa yang disebabkan oleh alam, misalnya letusan gunung berapi, tanah longsor, gempa bumi. 
2. Bencana nonalam yaitu bencana yang diakibatkan oleh peristiwa atau rangkaian peristiwa nonalam, misalnya pencemaran lingkungan, kebakaran lahan yang disebabkan oleh manusia, ledakan nuklir.

3. Bencana sosial yaitu bencana yang diakibatkan oleh peristiwa yang diakibatkan oleh manusia sendiri, misalnya kerusuhan dan konflik sosial.

Rawan bencana adalah kondisi atau karakteristik geologis, biologis, hidrologis, klimatologis, geografis, sosial, budaya, politik, ekonomi, dan teknologi pada suatu wilayah untuk jangka waktu tertentu yang mengurangi kemampuan mencegah, meredam, mencapai kesiapan, dan mengurangi kemampuan untuk menanggapi dampak buruk bahaya tertentu.

\subsection{Tableau}

Tableu adalah salah satu aplikasi BI berfungsi membuat visualisasi yang meningkatkan pemahaman pembaca tentang informasi dengan menghasilkan data dengan cara mengimport data set ke dalam Tableau. Tableau menggunakan akses langsung ke gudang data yang memungkinkan pengguna membuat informasi yang berguna di Tableau. Pengguna dapat mengekstrak data dari tampilan atau menghubungkannya secara langsung. Tableau dapat mengurangi waktu pembuatan laporan dengan dasbor yang mudah dipahami. Dengan penggunaan Tableau dapat lebih meningkatkan analitik pemerintahan dengan kecepatan, akurasi, transparansi, dan kemudahan komunikasi tambahan (Tableau, 2018).

Tableau digunakan dalam menganalisis data untuk dapat membantu dalam proses pengambilan keputusan diperusahaan atau organisasi. Tableau Desktop, server, online, dan public. Tableau juga bisa memvisualisasikan data spasial (data peta) melalui plug-in di dalamnya (Silvana et al, 2017). Tableau juga dapat menampilkan data spasial melalui plugin OpenStreetMap bawaan. OpenStreetMap ialah proyek pemetaan yang dibangun oleh komunitas kartografer untuk menyediakan dan memelihara data tentang jalan, jalan setapak, kafe, stasiun, dan lainnya di seluruh dunia. OpenStreetMap menggunakan data terbuka yang dilisensikan dari OpenStreetMap Foundation (OSMF) di bawah Open Data Commons Open Database License (ODbL). 


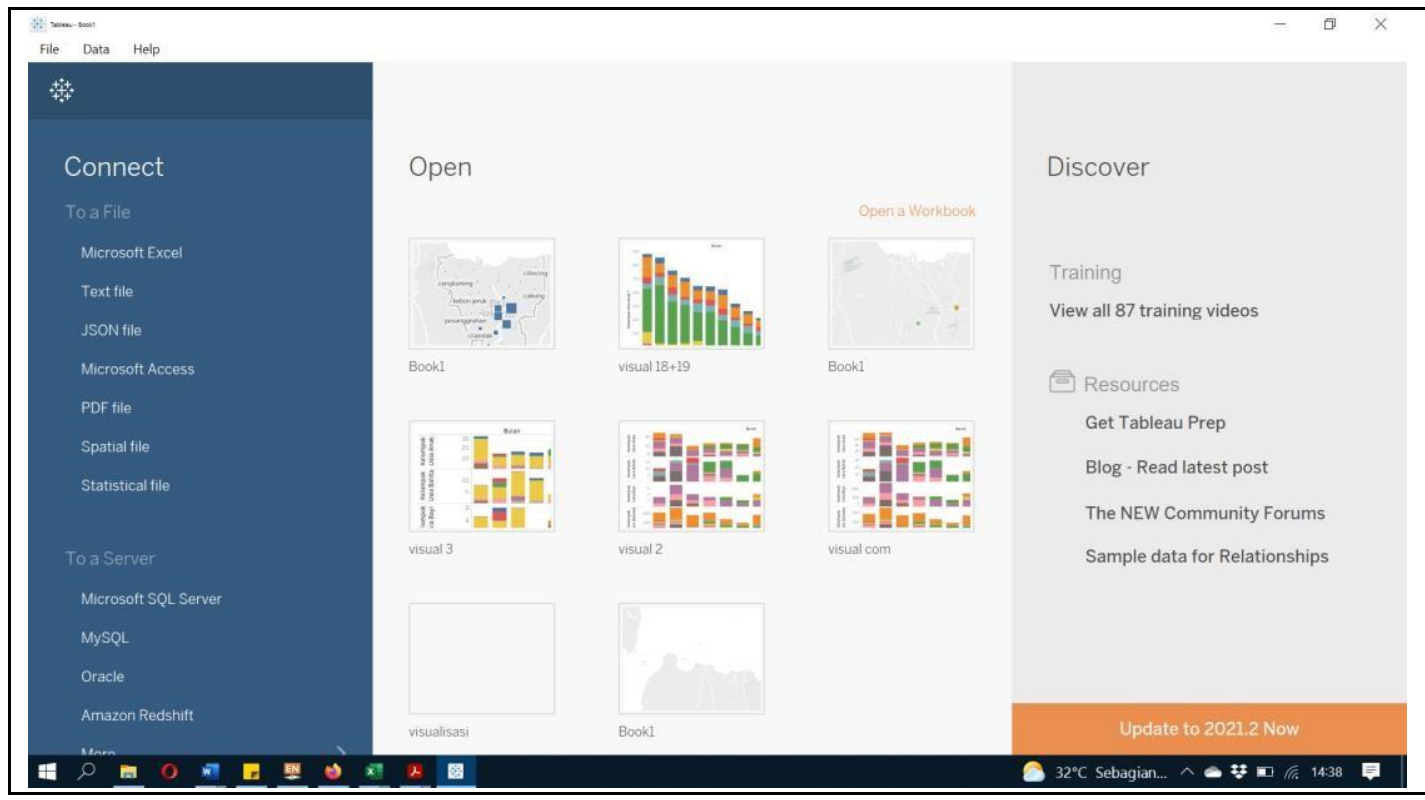

Gambar 2. 2 Tampilan Tableau Desktop

Beberapa penelitian terdahulu yang menjadi acuan penulis untuk melakukan penelitian pemanfaatan $B I$ dalam melakukan visualisasi.

Penelitian Darman (2018) berjudul Pembangunan Dashboard Lokasi Rawan Tanah Longsor di Indonesia Menggunakan Tableau. Penelitian bertujuan untuk memanfaatkan data yang ada pada BPBD untuk menjadikan sebuah sistem informasi eksekutif yang dapat menampilkan informasi tentang kondisi bencana yang terjadi di Indonesia. Pemanfaatan business intelligence dengan memanfaatkan tools Tableau untuk melakukan visualisasi yang dapat mengelompokkan provinsi di Indonesia berdasarkan data yang telah didapat dengan output berupa informasi dashboard. Hasil yang didapat yaitu 7 Kesimpulan dari dashboard yang terbentuk salah satunya ialah Jawa Barat merupakan daerah yang paling rawan akan bencana tanah longsor.

Penelitian dari Marizka et al (2018) dengan judul Implementasi Business Intelligence Menentukan Daerah Rawan Gempa Bumi di Indonesia dengan Fitur Geolokasi. Tujuan dari penelitian ini memanfaatkan data gempa bumi dari BNPB untuk dijadikan suatu informasi yang lebih bernilai dengan memanfaatkan business intelligence. Penelitian menggunakan salah satu aplikasi business inteligence yakni QlikView untuk dapat mengelompokkan bencana gempa bumi yang terjadi di setiap provinsi yang ada di Indonesia serta menampilkan visualisasinya pada peta dengan fitur geolokasi menggunakan data spasial. Hasil yang didapatkan dalam melakukan visualisasi yaitu ada 7 dashboard yang terbentuk salah hasilnya ialah Daerah tepi barat pantai Sumatera, selatan Pulau Jawa, Maluku Utara, Kepulauan Nusa Tenggara dan utara Pulau Papua merupakan daerah paling rawan gempa bumi pada tahun 2010 - 2014.

Penelitian Camila et al (2018) berjudul Visualisasi Perbandingan APBD Dan Realisasi Anggaran Kabupaten/Kota Se-Sumatra Barat Menggunakan Tableau Public. Penelitian ini bertujuan menganalisis dan mengetahui persebaran pemetaan dana anggaran yang diberikan dengan memanfaatkan business intelligence. Tools yang digunakan yaitu Tableau Public dengan hasil yang didapatkan yaitu Provinsi Sumatra Barat setiap tahunnya memfokuskan APBD pada ibukota provinsi-nya, yaitu Padang. Serta adanya 
Selisih tertinggi berada pada tahun 2013 yang selisihnya mendekati 1 triliun. Serta hampir semua nilai realisasi pada rentang waktu 2009 hingga tahun 2013 ditiap kabupaten/kota lebih rendah dibanding nilai APBD yang dianggarkan pada awalnya.

\section{Metode Penelitian}

Dalam Metodologi Penelitian ada beberapa poin yang dijelaskan yaitu metode penelitian, dan metode pengumpulan data.

\subsection{Metode Penelitian}

Metode penelitian yang digunakan penulis yaitu penelitian kuantitatif dan analisis deskriptif (Fauzi, Dencik \& Asiati, 2019) yang bertujuan menggambarkan secara sistematis dan faktual tentang fakta-fakta serta hubungan antar variabel yang diselidiki dengan cara mengumpulkan data, mengolah, menganalisis, dan menginterpretasi data [4]. Berikut merupakan alur penelitian yang digunakan penulis untuk melakukan penelitian dapat dilihat pada gambar 1 .

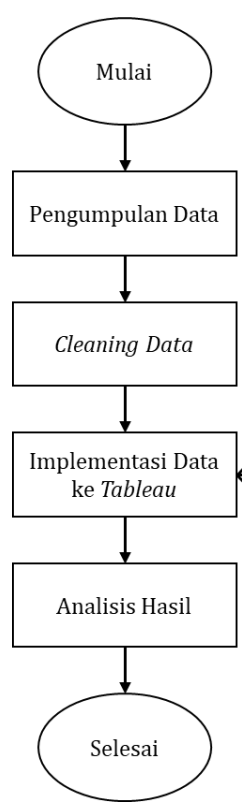

Gambar 1. Alur Penelitian

\subsection{Metode Pengumpulan Data}

Adapun metode pengumpulan data yang digunakan dalam menyelesaikan penelitian ini, antara lain:

1) Wawancara dan pengumpulan dataset

Penulis akan melakukan wawancara untuk mengetahui wilayah rawan bencana yang terjadi di wilayah Sumatera Selatan. Dan juga penulis akan mengambil data wilayah rawan bencana dari tahun 2018-2020.

2) Studi Pustaka

Penulis juga mencari penelitian-penelitian terdahulu untuk dijadikan referensi dalam melakukan visualisasi dan informasi dashboard menggunakan Tableau. 


\subsection{Tahapan Business Intelligence}

Business Intelligence memiliki beberapa tahapan dalam pengolahan datanya berikut tahapan yang digunakan menurut Atsani, et al. ]

1) Data Source, yaitu sumber data yang akan digunakan untuk membuat data warehouse. Sumber data biasanya didapat dari database (sqlserver, oracle, mysql) dan juga dalam format file ( $x l s x, c s v, x m l$, dan json).

2) Extract Transform Loading (ETL), merupakan suatu proses pengolahan/Penyaringan data dari database transactional ke data warehouse.

3) Data warehouse, ialah database yang dibuat untuk menganalisis dan pelaporan, beberapa model yang biasa digunakan dalam pembuatan data warehouse yaitu model skema bintang dan skema snowflake.

4) Data model, yaitu metode yang digunakan untuk melakukan analisis data dari data warehouse secara multidimensi.

5) Dashboard, merupakan bentuk visualisasi data dalam bentuk teks, peta maupun grafik.

\subsection{Information Dashboard}

Penggunaan informasi dashboard berguna untuk mempercepat proses keputusan, mengukur kinerja organisasi/instansi, memonitor proses yang sedang berjalan dan memprediksi kondisi di masa yang akan datang. Dashboard merupakan tools dan menyajikan key perfomence indicators (KPI) merupakan indikator utama dari kinerja suatu proses yang berlangsung pada sebuah organisasi yang menampilkan dalam satu layar untuk memudahkan suatu proses sehingga dapat meningkatkan proses bisnisnya. Terdapat beberapa prinsip yang harus diperhatikan dalam membuat dashboard, yaitu :

1) Menyediakan informasi berupa key performance indicator yang spesifik.

2) Melakukan integrasi beberapa informasi dalam 1 layar.

3) Bersifat interaktif dan informasi yang saling terintegrasi.

4) Melakukan analisis, monitoring, dan prediksi dalam 1 waktu.

5) Dapat bersifat personal menyesuaikan kebutuhan dari penggunaan.

6) Memeungkinkan berkolaborasi dan komunikasi antar bagian divisi

\section{Hasil dan Pembahasan}

Pada penelitian ini penulis menggunakan tahapan pengembangan business Intelligence menurut penelitian (Atsani, et al.) ] yang dimana memiliki beberapa tahapan. data source menjadi tahapan utama dalam pengambilan data, dilanjutkan dengan data warehouse yang dimana proses tersebut harus melalui ETL yang merupakan proses pengolahan ataupun penyaringan data, dan data model digunakan untuk menganalisis hasil visualisasi yang akan dilakukan, dan tahapan terakhir merupakan dashboard yang terbentuk sesuai dengan visualisasi yang terbentuk dari data model.

\subsection{Proses Eksekusi Data}

Data yang didapat merupakan data excel dengan atribut bulan, tahun, kecamatan, jenis bencana, jenis kerusakan, jumlah kerusakan, satuan, korban KK, korban Jiwa, korban kk, bantuan, dan kekurangan. Data akan diubah yang semula tipe file $x l s x$ menjadi database dan kemudian 
dilakukan penyeleksian atribut. Berikut dataset file tahun 2018-2020 dengan tipe data $x l s x$ yang belum dilakukan seleksi atribut, proses pengambilan atribut yang dibutuhkan dan disimpan dalam bentuk database yang dihubungkan pada SQLyog dengan database bpbd_bencana dapat dilihat pada gambar 2 .

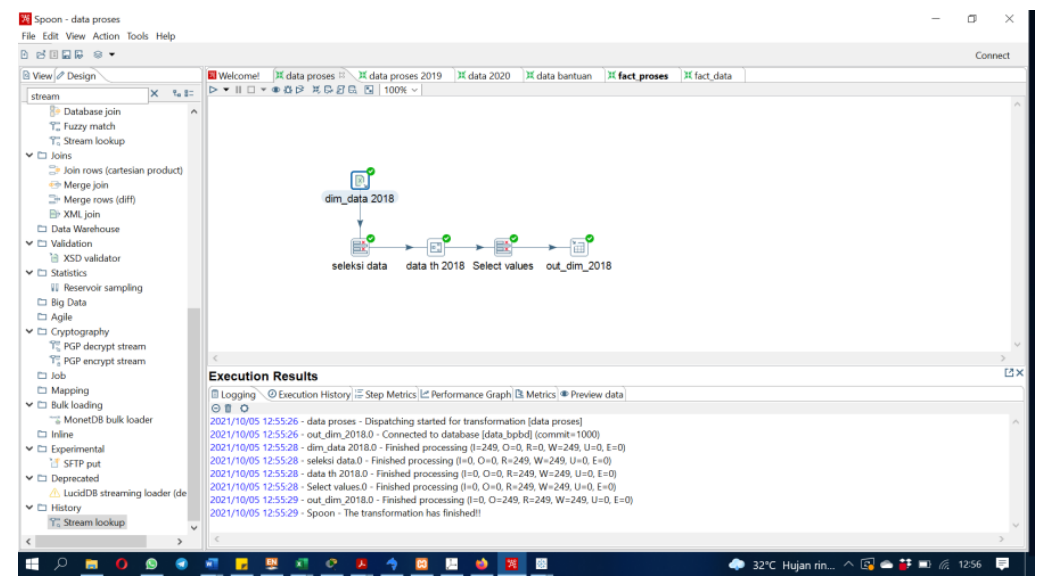

Gambar 2. Proses Seleksi Data

Setelah melakukan proses data, hasil yang didapatkan berupa indikator yang akan dilakukan visualisasi di tahun 2018, atribut yang diambil yaitu bulan, tahun, kecamatan, jenis bencana, jenis kerusakan, jumlah kerusakan, satuan, korban KK, korban Jiwa, dan korban kk. Dalam membangun data warehouse diperlukannya suatu tempat untuk mendapatkan hasil dimensi yang telah dilakukan, penulis menggunakan SQLyog untuk menyimpan hasil dari proses yang telah dilakukan pada Pentaho. Berikut hasil penyimpanan dari database yang telah diproses dari Pentaho.

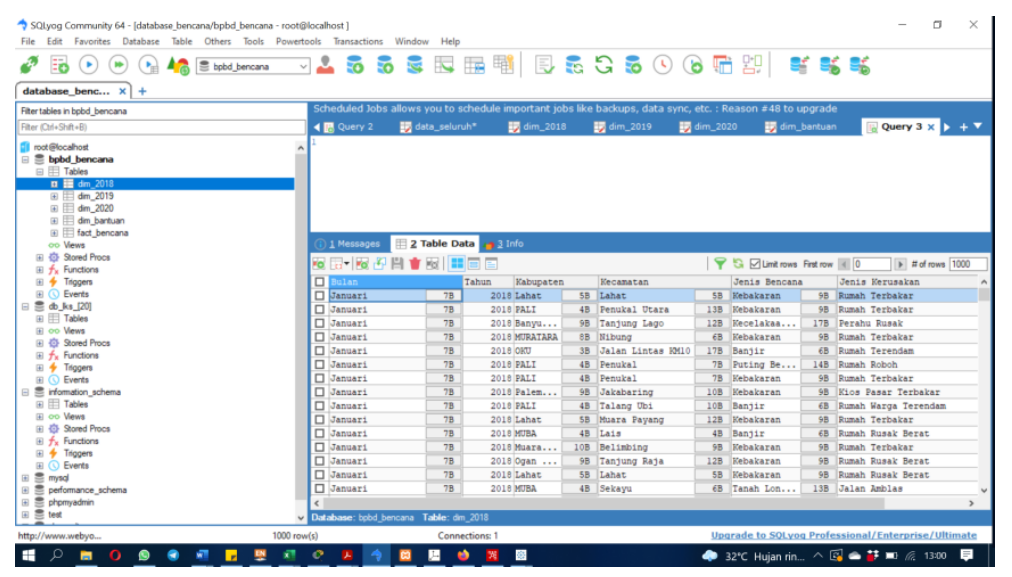

Gambar 3. Hasil Penyimpanan Data di SQLyog

\subsection{Data Warehouse}

Pada data warehouse didapatkan sebuah model skema bintang dengan adanya tabel fakta. Penulis menggunakan tools Olabcube dalam membentuk skema bintang dengan melakukan koneksi dari database bpbd_bencana. Berikut merupakan hasil skema yang didapatkan. 


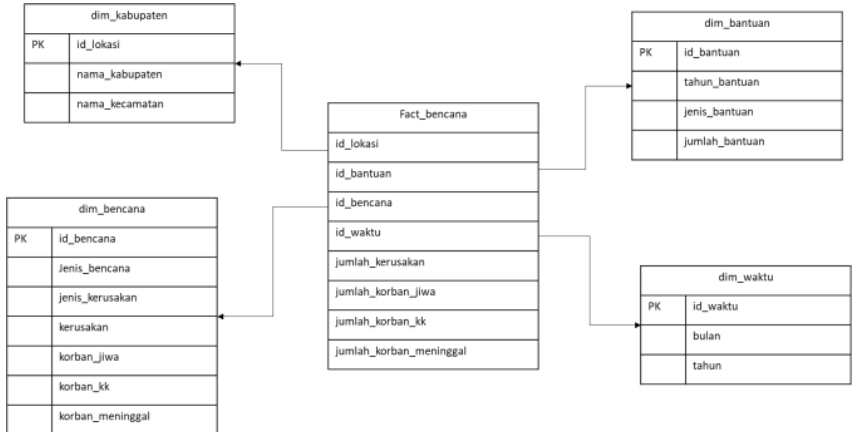

Gambar 4. Skema Bintang

\subsection{Visualisasi Bantuan Bencana}

Rekapan data yang didapatkan mengenai paket bantuan dari bencana yang terjadi dari tahun 2018-2020 dimana penulis melakukan visualisasi dengan mengambil 5 bantuan yang sering disalurkan pada setiap Kabupaten Kota yang terdampak bencana. Berikut hasil visualisasi yang didapatkan.

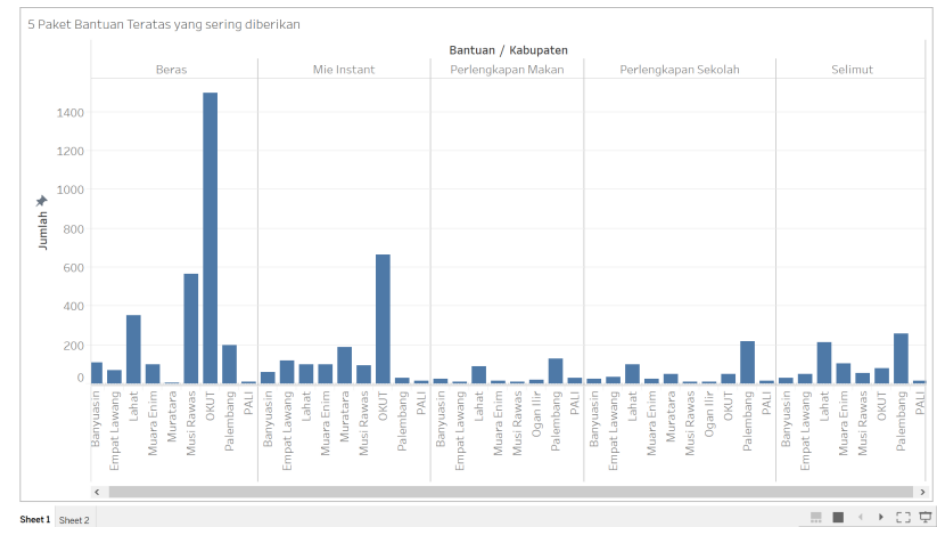

Gambar 5. Visualisasi Bantuan Bencana

\subsection{Information Dashboard}

Pembentukan informasi dashboard juga dilakukan dalam penggabungan data pada tahun 20182020. Hal ini untuk mendapatkan suatu kesimpulan akhir yang dimana bencana yang sering terjadi, lokasi yang rawan bencana tersebut dan dengan korban tercatat. Berikut hasil dashboard yang terbentuk dengan data dari tahun 2018-2020.

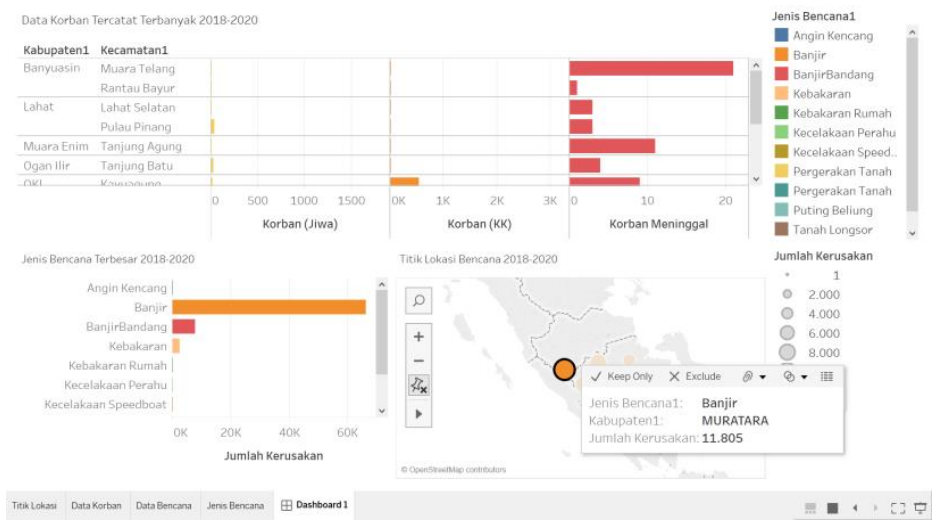

Gambar 6. Information Dashboard 
Dari informasi yang terbentuk bahwa banjir merupakan bencana yang sering terjadi dibeberapa lokasi dengan data akumulasi kerusakan paling banyak berada pada Kabupaten Musi Rawas Utara sebanyak 11.805.

\section{Kesimpulan}

Dari hasil visualisasi dan informasi Dashboard yang dibuat, penulis mendapatkan hasil akhir bahwa bantuan yang sering dikirimkan berupa beras, mie instant, perlengkapan makan, perlengkapan sekolah dan selimut. Pada informasi dashboard didapatkan akumulasi kerusakan oleh bencana yaitu 11.805 dengan bencana yang sering terjadi yaitu banjir dengan wilayah yang sering terjadi banjir yaitu Kabupaten Musi Rawas Utara.

\section{Referensi}

Akbar, R., Rasyiddah, D., Anrisya, M., Julyazti, N. F., \& Syaputri, S. (2018). Penerapan Aplikasi Power Business Intelligence Dalam Menganalisis

Antoni, D., \& Akbar, M. (2019). E-supply chain management value concept for the palm oil industry. Jurnal Sistem Informasi, 15(2), 15-29.

Antoni, D., Fikari, D., \& Akbar, M. (2018). The readiness of palm oil industry in enterprise resource planning. Telkomnika, 16(6), 2692-2702.

Antoni, D., Herdiansyah, M. I., Akbar, M., \& Sumitro, A. (2021). Pengembangan Infrastruktur Jaringan Untuk Meningkatkan Pelayanan Publik di Kota Palembang. JURNAL MEDIA INFORMATIKA BUDIDARMA, 5(4), 1652-1659.

Antoni, D., Jie, F., \& Abareshi, A. (2020). Critical factors in information technology capability for enhancing firm's environmental performance: case of Indonesian ICT sector. International Journal of Agile Systems and Management, 13(2), 159-181.

Atsani, M. R., Anjari, G. T., \& Saraswati, N. M. (2019). Pengembangan Business Intelligence Di Rumah Sakit (Studi Kasus: Rsud Prof. Dr. Margono Soekarjo Purwokerto). Telematika, 12(2), 124-138.

BPBD. (2020). Data Bencana Kasus 2020. Sumatera Selatan: BPBD

Camila, C., Akbar, R., Sutria, M. I., Suri, N., \& Chairunnissa, S. (2018). Visualisasi Perbandingan Apbd Dan Realisasi Anggaran Kabupaten/Kota Se-Sumatra Barat Menggunakan Tableau Public. Jurnal Teknologi Informasi Mura, 10(2), 75-82.

Darman, R. (2018). Analisis Visualisasi Dan Pemetaan Data Tanaman Padi Di Indonesia Menggunakan Microsoft Power Bi. Jurnal Ilmiah Rekayasa dan Manajemen Sistem Informasi, 4(2), 156-162.

Darman, R. (2018). Pembangunan Dashboard Lokasi Rawan Tanah Longsor di Indonesia Menggunakan Tableau. Jurnal Teknik Informatika dan Sistem Informasi, 4(2), 256-269256-269.

Fauzi, F., Dencik, A. B., \& Asiati, D. I. (2019). Metodologi Penelitian untuk manajemen dan akuntansi. Jakarta: Salemba Empat.

Hafidz, I., Mirfak, A., Azhari, A., Adianto, A. I., Fuad, B. H., \& Farabi, M. I. (2019). Rancang Bangun Dashboard Dan Visualisasi Data Kickstarter Dengan Pendekatan Business Intelligence. SISFO VOL 8 NO 2, 2. 
Hartama, D. (2018). Analisa Visualisasi Data Akademik Menggunakan Tableau Big Data. Jurasik (Jurnal Riset Sistem Informasi dan Teknik Informatika), 3, 46-55.

Imam, T. (2016). Perancangan Data Warehouse Untuk Mndukung Kebutuhan Informasi Penjualan dalam Pengambilan Keputusan (Studi kasus: Sesko Mart). Tugas Akhir Universitas Widyatama.

Indonesia, P. R. (2007). Undang-undang Republik Indonesia Nomor 24 Tahun 2007 tentang Penanggulangan Bencana. Jakarta: Sekretariat Negara.

Informasi Geografis (Sig) Di Provinsi Jawa Timur. Universitas Brawijaya, Marizka, F., Akbar, R., Darman, R., Namora, J., \& Ardewati, N. (2018). Implementasi Business Intelligence Menentukan Daerah Rawan Gempa Bumi di Indonesia dengan Fitur Geolokasi. JEPIN (Jurnal Edukasi dan Penelitian Informatika), 4(1), 30-35.

Khakimuddi, M. A. (2018). Pemetaan Zona Bencana Tanah Longsor Dengan Pemodelan Algoritma Monte Carlo Dan Hec-Ras Berbasis Sistem

Nurmalasari, D., Wahyuni, R. T., \& Palapa, Y. (2015). Informational Dashboard untuk Monitoring Sistem Drainase secara Real-Time. Jurnal Nasional Teknik Elektro dan Teknologi Informasi (JNTETI), 4(3), 141-146.

Prioritas Pekerjaan di Indonesia. J. Edukasi dan Penelit. Inform, 4(1), 54. Alfarizi, V., Akbar, R., Amarta, T. B., Ardian, N. N., \& Ibrahim, M. J. (2018). Implementasi Business Intelligence untuk Mendapatkan Pola Penerbangan Penumpang Pesawat dari atau ke Bandara Internasional Minangkabau. JEPIN (Jurnal Edukasi dan Penelitian Informatika), 4(1), 65-69.

\section{Copyrights}

Copyright for this article is retained by the author(s), with first publication rights granted to the journal.

This is an open-access article distributed under the terms and conditions of the Creative Commons Attribution license (http://creativecommons.org/licenses/by/4.0/) 